\title{
Early and late Iron supplementation for low birth weight infants: a meta-analysis
}

\author{
Hong-Xing Jin, Rong-Shan Wang*, Shu-Jun Chen, Ai-Ping Wang and Xi-Yong Liu
}

\begin{abstract}
Background: Iron deficiency in infancy is associated with a range of clinical and developmentally important issues. Currently, it is unclear what is the optimal timing to administer prophylactic enteral iron supplementation in preterm and very low birth weight infants. The objective of this meta-analysis was to evaluate early compared with late iron supplementation in low birth weight infants.
\end{abstract}

Methods: PubMed and Cochrane Library databases were searched up to May 10, 2014 for studies that compared the benefit of early and late iron supplementation in infants of low birth weight. Sensitivity analysis was carried out using the leave one-out approach and the quality of the included data was assessed.

Results: The data base search and detailed review identified four studies that were included in the meta-analysis. The number of included patients was 246 ( $n=121$ for early supplementation and $n=125$ for late supplementation) and the majority were premature infants. Across studies, early supplementation ranged from as early as enteral feeding was tolerated to 3 weeks, and late supplementation ranged from 4 weeks to about 60 days. Early treatment was associated with significantly smaller decreases in serum ferritin and hemoglobin levels $(P<0.001)$. In addition, the rate of blood transfusions was lower with early compared with late iron supplementation $(P=0.022)$. There was no difference between early and late supplementation in the number of patients with nectorizing enteroclitis (>bell stage 2) $(P=0.646)$. Sensitivity analysis indicated no one study overly influenced the findings and that the data was reliable.

Conclusion: In conclusion, early iron supplementation resulted in less a decrease in serum ferritin and hemoglobin levels in infants with low birth rate. However, caution should be used when treating infants with iron so as not to result in iron overload and possibly negative long-term effects on neurodevelopment.

Keywords: Iron, Supplementation, Low birth weight, Infant, Meta-analysis

\section{Introduction}

Iron is an essential nutrient and plays a key role in many processes including growth and development. Iron deficiency in infancy is associated with a range of clinical and developmentally important issues including neurodevelopmental deficits, delayed maturation of the auditory brainstem response, and abnormalities of memory and behavior [1,2]. Iron deficiency is estimated to range between $25 \%$ and $80 \%$ in preterms during infancy $[3,4]$. Low birth weight infants are particularly susceptible to developing iron deficiency anemia since they typically have small iron stores at birth and a greater need for iron due to the rapid increase in red cell mass [5-7].

\footnotetext{
* Correspondence: wrs1996@sina.com

Yiwu Maternity and Child Care Hospital, No.320 Nanmen Street, Yiwu 32200Zhejiang, China
}

Other factors that may impact development of iron deficiency anemia in low birth weight infants are preterm birth, maternal conditions (such as diabetes mellitus, hypertension, smoking, etc.) increased hemolysis, reduced red blood cell life span, low circulating erythropoietin levels, blood sampling, and loss of blood due to surgery $[1,3,8]$.

A number of studies have found that iron supplementation increases the levels of hematologic indicators or iron status and reduces the frequency of anemia or iron deficiency in low birth weight or premature infants $[8,9]$. One concern with iron supplementation is that free ferrous iron may increase oxidative stress via the production of free radicals [6]. Hence, it is important to prevent not only iron deficiency but also iron overload. Currently, it is unclear at what time to administer prophylactic iron

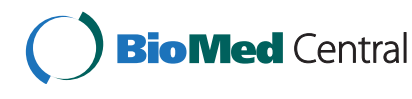

(C) 2015 Jin et al.; licensee BioMed Central. This is an Open Access article distributed under the terms of the Creative Commons Attribution License (http://creativecommons.org/licenses/by/4.0), which permits unrestricted use, distribution, and reproduction in any medium, provided the original work is properly credited. The Creative Commons Public Domain Dedication waiver (http://creativecommons.org/publicdomain/zero/1.0/) applies to the data made available in this article unless otherwise stated. 
supplementation in preterm very low birth weight infants [10]. In fact, the different international associations recommend different timings for initiation of iron supplementation for these babies [10]. European Society for Paediatric Gastroenterology, Hepatology, and Nutrition Committee on Nutrition recommends prophylactic enteral iron supplementation (given as a separate iron supplement, in preterm formula or in fortified human milk) should be started at 2 to 6 weeks of age (2-4 weeks in extremely-low-birth weight infants) [11]. The Canadian Pediatric Society suggests for infants with low birth weight $(<1000 \mathrm{~g})$ they should receive a total intake of $3-4 \mathrm{mg} / \mathrm{kg}$ per day starting at $6-8$ weeks after birth [12]. The American Academy of Pediatric recommend that that a preterm infant who is fed milk should receive a supplement of elemental iron at $2 \mathrm{mg} / \mathrm{kg}$ per day starting by 1 month of age and extending through 12 months of age [13]. The objective was to gain insight into the importance of timing of iron supplementation by evaluating early compared with late iron supplementation in low birth weight infants.

\section{Methods}

\section{Search strategy}

PubMed and Cochrane Library databases were searched up to May 10, 2014 for studies that compared the benefit of early and late iron supplementation in infants of low birth weight. Search terms included premature birth, preterm birth, premature infant, preterm infant, low birth weight infant, iron supplementation, early, and late. The search also included: (premature birth OR preterm birth OR low birth weight) AND (iron deficiency OR iron supplement OR iron). Included studies were randomized controlled prospective trials whose patient population were low birth weight infants $(<2500 \mathrm{~g})$ or premature infants (gestational age $<37$ weeks). Eligible studies used an intervention that involved iron supplementation (any kind), and had to compare the effect of early and late iron supplementation. Early supplementation was considered between 2-3 weeks postnatal age and late supplementation was defined as $>4$ weeks postnatal age. Studies were included if they evaluated infants who could tolerate enteral feeding (usually $>2$ weeks of age). Studies were excluded if they were single arm and did not evaluate serum ferritin and hemoglobin levels. Studies were also excluded if the intervention was combined with erythropoietin treatment, andif they were non-English, case reports, letters, or comments.

\section{Data extraction}

The following data was extracted: author's first name, study design, inclusion criteria, iron source, early or late supplementation, dosing route, number of subjects, gestational age, birth weight, gender, and time of evaluation.
Also the level of serum ferritin $(\mathrm{ng} / \mathrm{mL})$ and hemoglobin before and after treatment was extracted as was the percent of subjects requiring blood transfusions and necrotizing enterocolitis (>bell stage 2). Two reviewers extracted the studies, and a third reviewer was consulted to resolve any disagreements.

\section{Quality assessment}

Quality assessment of the included studies was based on Cochrane handbook version 5.1.0 Chapter 8 "Assessing risk of bias in included studies" table for validity assessment of eligible trials [14].

\section{Statistical analysis}

The changes in serum ferritin and hemoglobin levels, blood transfusion rate, and necrotizing enterocolitis rate were compared between participants who received early supplementation and participants who received late supplementation. For the continuous data, changes in serum ferritin levels and hemoglobin levels, the data were represented as mean \pm standard deviation (SD) or mean (range: min, max) for a given group in each study. The effect size was calculated as difference in means of outcomes after iron supplementation between early and late groups with estimated 95\% confidence intervals $(95 \% \mathrm{CI})$ and corresponding $\mathrm{P}$ values. For those data with mean (range), the $\mathrm{SD}$ was utilized according to the equation $\mathrm{SD}=$ Range/ 4before analysis [15]. The difference in means of outcomes greater than 0 indicated the late group was favored. The difference in means of outcomes lower than 0 indicated the early group was favored. If the means difference was zero than both the early and late groups had similar change in outcomes. For blood transfusion and necrotizing enterocolitis rates, data were represented as events/ total participants for a given group in each study.

The effect size was calculated as odd ratio (OR) of outcomes after iron supplementation with estimated 95\% CI between early and late groups and corresponding $\mathrm{P}$ values. OR $>1$ indicates late group had higher rate than early group; $\mathrm{OR}<1$ indicates late group had lower rate than early group; $\mathrm{OR}=0$ indicated both groups had similar rate. A $\mathrm{X}^{2}$ based test of homogeneity was performed using Cochran's Q statistic and $\mathrm{I}^{2} . \mathrm{I}^{2}$ indicates the percentage of the total variability in effect estimates among trials due to heterogeneity rather than chance. Random-effects model of analysis (DerSimonian-Laird method) was used if heterogeneity was detected $\left(\mathrm{I}^{2}>50 \%\right.$ or P-value $\left.<0.05\right)$. Otherwise, fixed-effects model (Mantel-Haenszel method) was used. For evaluation, a combined difference in mean with 95\% CI for continuous outcomes and OR (95\% CI) for categorical variables were calculated for the pooled study results. A two-sided $\mathrm{P}$ value $<.05$ was taken to indicate statistical significance for one comparison group over the other. Sensitivity analysis was carried out for the outcomes 
using the leave-one-out approach. Publication bias was not performed because more than five studies are required to detect funnel plot asymmetry [16]. All analyses were performed using Comprehensive Meta-Analysis statistical software, version 2.0 (Biostat, Englewood, NJ).

\section{Results}

The search of the databases identified 330 studies of with 312 were excluded as not being relevant (Figure 1). Eighteen studies were evaluated in detail and 13 were excluded due to being a single arm study $(n=2)$, did not compare early versus late iron supplementation $(\mathrm{n}=10)$, or did not report an outcome of interest $(n=1)$. Five studies were identified and their data extracted [17-20] However, the study of Franz et al. [21] was not included in the meta-analysis due to lack of detail in sample size for the outcomes evaluated. Hence, only four studies were used for the meta-analysis [17-20].

\section{Study characteristics}

All the studies included babiess with low birth weight with premature babies being the most common (Table 1). The mean gestational age of participants (ranged from 26.7 to 32.4 weeks) was similar between studies and between groups within studies. The source of iron included colloidal iron, iron trivalent (III)-hydroxide polymaltose complex, ferrous sulfate, and ferrous succinate. The number of participants in each study ranged from 15 to $105(\mathrm{n}=226)$ for the early supplementation group and from 13 to $99(\mathrm{n}=224)$ for the late supplementation group. About $50 \%$ of the infants were male and the time of evaluation ranged from 1-2 days to 6 months. Early treatment ranged from as early as enteral feeding was tolerated [21] to 2 [17-19] or 3 weeks [20]. Late supplementation ranged from 4 weeks [17] to about 60 days [18,20,21].

Generally, across all studies serum ferritin and hemoglobin numerically decreased following either early or late iron supplementation (Table 2). In the different studies the serum ferritin was measured by enzyme immunoassay and the method sensitivity ranged from $1-2.5 \mathrm{ng} / \mathrm{ml}$ and specificity of about $100 \%$. Hemoglobin was estimated by Coulter LH 750 analyzer and the specificity and sensitivity for this assay are not reported. The percent of patients requiring blood transfusions was numerically higher for those receiving late iron supplementation compared to those receiving early supplementation. Necrotizing enterocolitis was similar between early and late iron supplementation.

\section{Quality assessment}

Overall the studies were of high quality. In three of the studies the participants and personnel were not blinded to treatment (Table 3). The remaining two studies did not describe blinding. Jansson et al. [20] did not describe if allocation was concealed or if outcome assessments were blinded. Only three of the studies describe that they included an intention-to-treat analysis.

\section{Serum ferritin level}

Four studies with serum ferritin data were included in the analysis [14-17]. A random effects analysis was applied because there was evidence of heterogeneity among the studies (Q statistic $=11.108, \mathrm{I}^{2}=72.99 \%, \mathrm{P}=.011$ ). The summarized difference in means of change of serum ferritin levels after iron supplementation significantly favored the early iron supplementary group (difference in means $=-14.54,95 \% \mathrm{CI}=-22.14$ to $-6.94, \quad \mathrm{P}<.001$ ) (Figure 2A). The magnitude of fall in serum ferritin level was smaller in the early compared with the late iron supplementation group.

\section{Hemoglobin level}

Three studies had complete hemoglobin data and were included in the analysis A fixed effects analysis was applied because there was no evidence of heterogeneity among the studies $\left(\mathrm{Q}\right.$ statistic $\left.=0.817, \mathrm{I}^{2}=0 \%, \mathrm{P}=.665\right)$. Similar to ferritin levels, the summarized difference in

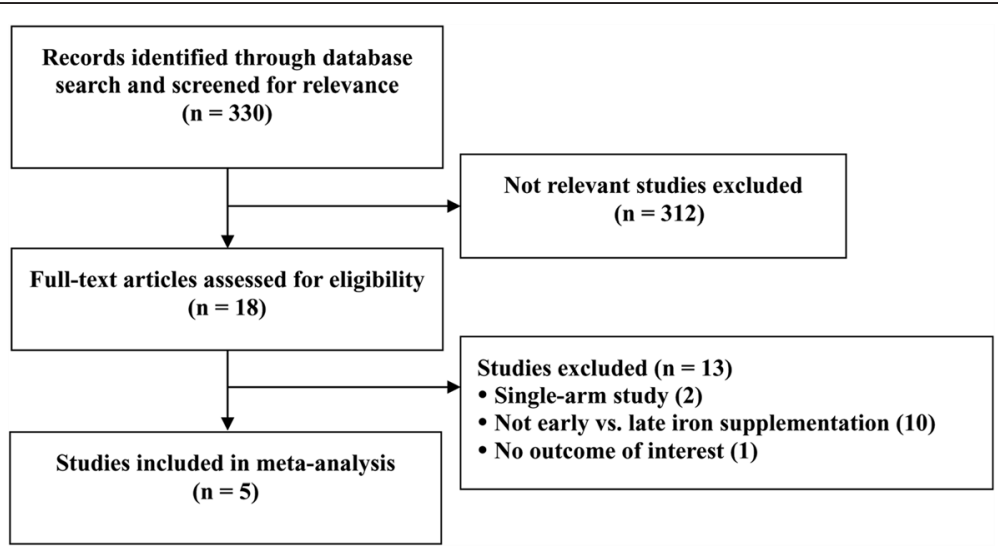

Figure 1 Flow diagram of study selection. 
Table 1 Summary of basic characteristics of selected studies

\begin{tabular}{|c|c|c|c|c|c|c|c|c|c|c|c|}
\hline Study \# & $\begin{array}{l}\text { 1st AU } \\
\text { (year) }\end{array}$ & $\begin{array}{l}\text { Study } \\
\text { design }\end{array}$ & Inclusion criteria & $\begin{array}{l}\text { Medical iron } \\
\text { source }\end{array}$ & Group & Route ; dose & $\begin{array}{l}\text { Number } \\
\text { of subject }\end{array}$ & $\begin{array}{l}\text { Gestation } \\
\text { age (weeks) }\end{array}$ & Birth weight (kg) & $\begin{array}{l}\text { Gender } \\
\text { (male/female) }\end{array}$ & $\begin{array}{l}\text { Evaluated } \\
\text { time point }\end{array}$ \\
\hline \multirow[t]{2}{*}{1} & \multirow[t]{2}{*}{ Joy [17] } & \multirow[t]{2}{*}{ RCT } & \multirow{2}{*}{$\begin{array}{l}\text { Intramural preterm (<37 weeks gestational } \\
\text { age) VLBW infants (birth weight } 1000-1500 \mathrm{~g} \text { ) } \\
\text { who reached full enteral feeds of } 180 \mathrm{~mL} / \mathrm{kg} / \\
\text { day by } 2 \text { weeks postnatal age }\end{array}$} & \multirow[t]{2}{*}{$\begin{array}{l}\text { colloidal ferric } \\
\text { hydroxide }\end{array}$} & early & $\begin{array}{l}\mathrm{PO} ; 2 \mathrm{mg} / \mathrm{kg} / \mathrm{day} \\
\text { start at } 2 \text { weeks } \\
\text { postnatal age }\end{array}$ & 52 & $32.4 \pm 1.7$ & $1.35 \pm 0.15$ & $27 / 23$ & 12 weeks \\
\hline & & & & & late & $\begin{array}{l}\mathrm{PO} ; 2 \mathrm{mg} / \mathrm{kg} / \mathrm{day} \\
\text { start at } 6 \text { weeks } \\
\text { postnatal age }\end{array}$ & 52 & $32.4 \pm 1.6$ & $1.33 \pm 0.14$ & $24 / 26$ & \\
\hline \multirow[t]{2}{*}{2} & \multirow[t]{2}{*}{ Sankar [18] } & \multirow[t]{2}{*}{ RCT } & \multirow{2}{*}{$\begin{array}{l}\text { Preterm VLBW }(<1500 \mathrm{~g}) \text { infants who } \\
\text { reached at least } 100 \mathrm{~mL} / \mathrm{kg} / \text { day of oral } \\
\text { feeds by day } 14\end{array}$} & \multirow[t]{2}{*}{ colloidal iron } & early & $\begin{array}{l}\mathrm{PO} ; 3-4 \mathrm{mg} / \mathrm{kg} / \mathrm{d} \\
\text { at } 2 \text { weeks }\end{array}$ & 22 & $32.4 \pm 1.8$ & $1.189 \pm 0.228$ & $12 / 10$ & 60 days \\
\hline & & & & & late & $\begin{array}{l}\text { PO; no iron until } \\
60 \text { days }\end{array}$ & 24 & $31.5 \pm 2.6$ & $1.213 \pm 0.196$ & $12 / 12$ & \\
\hline \multirow[t]{2}{*}{3} & \multirow[t]{2}{*}{ Arnon [19] } & \multirow[t]{2}{*}{ RCT } & \multirow[t]{2}{*}{$\begin{array}{l}\text { All infants with a gestational age of } \\
32 \text { weeks who were fed human milk and } \\
\text { reached enteral intake of } 100 \mathrm{~mL} / \mathrm{kg} / \mathrm{d}\end{array}$} & \multirow[t]{2}{*}{$\begin{array}{l}\text { Iron trivalent } \\
\text { (III)- } \\
\text { hydroxide } \\
\text { polymaltose } \\
\text { complex }\end{array}$} & early & $\begin{array}{l}\mathrm{PO} ; 5 \mathrm{mg} / \mathrm{kg} / \mathrm{d} \\
\text { enteral iron } \\
\text { polymaltose } \\
\text { complex at } \\
2 \text { weeks }\end{array}$ & 32 & $30(27,32) \dagger$ & $1.248(0.859,1.960) \dagger$ & $18 / 12$ & 8 weeks \\
\hline & & & & & late & $\begin{array}{l}\mathrm{PO} ; 5 \mathrm{mg} / \mathrm{kg} / \mathrm{d} \\
\text { enteral iron } \\
\text { polymaltose } \\
\text { complex at } \\
4 \text { weeks }\end{array}$ & 36 & $29(27,32) \dagger$ & $1.072(0.830,2.173) \dagger$ & $14 / 16$ & \\
\hline \multirow[t]{2}{*}{4} & \multirow[t]{2}{*}{ Franz [21] } & \multirow[t]{2}{*}{ RCT } & \multirow[t]{2}{*}{$\begin{array}{l}\text { All inborn infants with a birth weight } \\
\text { of }<1301 \mathrm{~g}\end{array}$} & \multirow[t]{2}{*}{ ferrous sulfate } & early & $\begin{array}{l}\mathrm{PO} ; 2-4 \mathrm{mg} / \mathrm{kg} / \mathrm{d} \\
\text { oral iron once } \\
\text { enteral feeding } \\
\text { was tolerated }\end{array}$ & 105 & $26.7(23,33)^{*}$ & $0.868(0.380,1.300)^{*}$ & na & 61 days \\
\hline & & & & & late & $\begin{array}{l}\mathrm{PO} \text {; started at } \\
61 \text { days of life at } \\
\text { a dose of } 2 \mathrm{mg} / \\
\mathrm{kg} / \text { day. }\end{array}$ & 99 & $26.9(23,35)^{*}$ & $0.872(0.370,1.300)^{*}$ & & \\
\hline \multirow[t]{2}{*}{5} & \multirow[t]{2}{*}{ Jansson [20] } & \multirow[t]{2}{*}{ RCT } & \multirow[t]{2}{*}{$\begin{array}{l}\text { LBW infants with a birth weight } \leqq 2000 \mathrm{~g} \\
\text { and/or a gestational age of } \leqq 35 \text { weeks }\end{array}$} & \multirow[t]{2}{*}{$\begin{array}{l}\text { ferrous } \\
\text { succinate }\end{array}$} & early & $\begin{array}{l}\mathrm{PO} ; 2-3 \mathrm{mg} / \mathrm{kg} / \\
\text { day from } \\
3 \text { weeks of age }\end{array}$ & 15 & All: $34(29-37)^{*}$ & $1.855 \pm 0.430$ & na & $\begin{array}{l}1-2 \text { days; } \\
8-10 \text { weeks; } \\
6 \text { months }\end{array}$ \\
\hline & & & & & late & $\begin{array}{l}\mathrm{PO} ; 2-3 \mathrm{mg} / \mathrm{kg} / \\
\text { day from } \\
2 \text { months of age }\end{array}$ & 13 & & $1.779 \pm 0.327$ & & \\
\hline
\end{tabular}

Gestational age and birth weight were presented as mean \pm SD.

*mean (range); tmedian (range).

na, not available; PO, per os;RCT, randomized clinical trial; VLBW, very low birth weight. 
Table 2 Summary of outcomes of selected studies

\begin{tabular}{|c|c|c|c|c|c|c|c|c|c|}
\hline \multirow[b]{2}{*}{ Study \# } & \multirow[b]{2}{*}{$\begin{array}{l}1 \text { st AU } \\
\text { (year) }\end{array}$} & \multirow[b]{2}{*}{ Group } & \multirow[b]{2}{*}{$\begin{array}{l}\text { number of } \\
\text { evaluated subject }\end{array}$} & \multicolumn{2}{|c|}{ Serum ferritin $(\mathrm{ng} / \mathrm{mL})$} & \multicolumn{2}{|c|}{ Hemoglobin (g/dL) } & \multirow[b]{2}{*}{ Blood transfusion (\%) } & \multirow[b]{2}{*}{$\begin{array}{l}\text { Necrotizing enterocolitis } \\
\text { (>bell stage } 2 \text { ) }\end{array}$} \\
\hline & & & & before & after & before & after & & \\
\hline \multirow[t]{2}{*}{1} & Joy [17] & early & 46 & $\begin{array}{l}112 \pm 5 \text { at } 2 \\
\text { weeks of age }\end{array}$ & $82 \pm 5$ & $\begin{array}{l}12.9 \pm 0.8 \text { at } \\
2 \text { weeks of } \\
\text { age }\end{array}$ & $10.1 \pm 0.4$ & $2(4.3 \%)$ & $3 / 46$ \\
\hline & & late & 47 & $\begin{array}{l}113 \pm 6 \text { at } 2 \\
\text { weeks of age }\end{array}$ & $63 \pm 3$ & $\begin{array}{l}13.1 \pm 0.6 \text { at } \\
2 \text { weeks of } \\
\text { age }\end{array}$ & $9.2 \pm 0.4$ & $7(14.8 \%)$ & $4 / 47$ \\
\hline \multirow[t]{2}{*}{2} & Sankar [18] & early & 22 & $\begin{array}{l}55.7 \pm 12.1 \text { at } \\
\text { enrollment }\end{array}$ & $50.8 \pm 11.5$ & na & na & $2(9.5 \%)$ & $1 / 21$ \\
\hline & & late & 24 & $\begin{array}{l}59.0 \pm 12.1 \text { at } \\
\text { enrollment }\end{array}$ & $45.3 \pm 11.9$ & & & $3(13.0 \%)$ & $0 / 23$ \\
\hline \multirow[t]{2}{*}{3} & Arnon [19] & early & 32 & $\begin{array}{l}94 \pm 27 \text { at } 2 \\
\text { weeks of age }\end{array}$ & $\begin{array}{l}46 \pm 20 \text { at } 8 \text { weeks } \\
\text { of age }\end{array}$ & $\begin{array}{l}12.5 \pm 0.9 \text { at } \\
2 \text { weeks of } \\
\text { age }\end{array}$ & $9.0 \pm 1$ at 8 weeks of age & $1 / 33(2.8 \%)$ & $1 / 32$ \\
\hline & & late & 36 & $\begin{array}{l}90 \pm 21 \text { at } 2 \\
\text { weeks of age }\end{array}$ & $\begin{array}{l}30 \pm 12 \text { at } 8 \\
\text { weeks of age }\end{array}$ & $\begin{array}{l}11.9 \pm 1.3 \text { at } \\
2 \text { weeks of } \\
\text { age }\end{array}$ & $7.4 \pm 0.7$ at 8 weeks of age & 10/46 (21.3\%) & $3 / 36$ \\
\hline \multirow[t]{2}{*}{4} & Franz [21] & early & 68 & $\begin{array}{l}85.5(18,282) * a t \\
\text { birth }\end{array}$ & $87.8(9,478)^{*}$ & na & na & 41/105 (39.0\%) & $6 / 105$ \\
\hline & & late & 65 & $\begin{array}{l}77.9(13,354)^{*} \text { at } \\
\text { birth }\end{array}$ & $74.2(9,682)^{*}$ & & & 53/99 (53.5\%) & $8 / 99$ \\
\hline \multirow[t]{2}{*}{5} & Jansson [20] & early & 15 & $\begin{array}{l}102(34-220) * a t 1-2 \\
\text { days of age }\end{array}$ & $\begin{array}{l}56(16-175)^{*} \\
\text { at } 8-10 \text { weeks } \\
\text { of age } 26(18-45)^{*} \\
\text { at } 6 \text { months of age }\end{array}$ & $\begin{array}{l}20.0 \pm 2.7 \text { at } \\
\text { birth }\end{array}$ & $\begin{array}{l}10.3 \pm 1.0 \text { at } 8-10 \text { weeks of age; } \\
11.5 \pm 0.7 \text { at } 6 \text { monthsof age }\end{array}$ & na & na \\
\hline & & late & 13 & $\begin{array}{l}\text { 1-2 days: } 100 \\
(45-200)^{*} \text { at } 1-2 \text { days } \\
\text { of age }\end{array}$ & $\begin{array}{l}72(21-170)^{*} \text { at } \\
8-10 \text { weeks of age } 28 \\
(10-115)^{*} \text { at } 6 \text { months } \\
\text { of age }\end{array}$ & $\begin{array}{l}19.1 \pm 2.9 \text { at } \\
\text { birth }\end{array}$ & $\begin{array}{l}9.7 \pm 1.0 \text { at } 8-10 \text { weeks of age } \\
11.5 \pm 0.5 \text { at } 6 \text { months of age }\end{array}$ & & \\
\hline
\end{tabular}

of age

*mean(range).

na, not available. 
Table 3 Quality assessment

\begin{tabular}{llllllll}
\hline $\begin{array}{l}\text { 1st AU } \\
\text { (year) }\end{array}$ & $\begin{array}{l}\text { Random } \\
\text { sequence } \\
\text { generation }\end{array}$ & $\begin{array}{l}\text { Allocation } \\
\text { concealment }\end{array}$ & $\begin{array}{l}\text { Blinding of } \\
\text { participants and } \\
\text { personnel }\end{array}$ & $\begin{array}{l}\text { Blinding of } \\
\text { outcome } \\
\text { assessment }\end{array}$ & $\begin{array}{l}\text { Incomplete } \\
\text { outcome data }\end{array}$ & $\begin{array}{l}\text { Selective } \\
\text { reporting }\end{array}$ & $\begin{array}{l}\text { Did the analysis include } \\
\text { an intention-to-treat } \\
\text { analysis? }\end{array}$ \\
\hline Joy [17] & $Y$ & $Y$ & $N$ & $Y$ & $Y$ & $Y$ & NA \\
Sankar [18] & $Y$ & $Y$ & $N$ & $Y$ & $Y$ & $Y$ & $Y$ \\
Arnon [19] & $Y$ & NA & NA & $Y$ & $Y$ & $Y$ & $N A$ \\
Franz [21] & $Y$ & $Y$ & $N$ & $N$ & $Y$ & $Y$ & $Y$ \\
Jansson [20] & $Y$ & NA & NA & NA & $Y$ & $Y$ & $Y$ \\
\hline
\end{tabular}

NA: not available; N: no;Y: yes.

means of change of hemoglobin levels after iron supplementation favored the early iron supplementation group (difference in means $=-1.07,95 \% \mathrm{CI}=-1.29$ to $-0.85, \mathrm{P}<.001$ ) (Figure 2B). The decrease in hemoglobin levels was smaller in the early compared with the late iron supplementation group.

\section{Blood transfusion}

Three studies were included in the analysis since they had complete data for the frequency of blood transfusions. A fixed effects analysis was used because there was no evidence of heterogeneity among the studies (Q statistic $=1.625$, $\left.\mathrm{I}^{2}=0 \%, \mathrm{P}=.444\right)$. The summarized $\mathrm{OR}=0.287$ with a $95 \% \mathrm{CI}=0.099$ to 0.834 indicating that early iron supplementation lowered the frequency of blood transfusion rate compared with late supplementation $(\mathrm{P}=.022)$ (Figure 2C).

\section{Necrotizing enterocolitis (> bell stage 2 )}

Three studies that had complete necrotizing enterocolitis data were included in the analysis. A fixed effects analysis was applied as there was no evidence of heterogeneity among the studies ( $\mathrm{Q}$ statistic $=1.242, \mathrm{I}^{2}=0 \%, \mathrm{P}=.537$ ). The summarized $\mathrm{OR}=0.755$ with a $95 \% \mathrm{CI}=0.227$ to 2.506 indicated there was no difference between early and late supplementation in the frequency of necrotizing enterocolitis $(\mathrm{P}=.646)$ (Figure $2 \mathrm{D})$.

\section{Sensitivity analysis}

We performed sensitivity analysis where the data was reevaluated after each study was removed in turn. The direction and magnitude of the combined estimates did not change markedly for ferritin levels (Figure 3A), hemoglobin levels (Figure 3B), frequency of blood transfusions (Figure $3 \mathrm{C}$ ), and the rate of developing necrotizing enterocolitis (Figure 3D) when any one study was removed. These findings indicate that the meta-analysis had good reliability and that no one study overly influenced the results.

\section{Discussion}

Our analysis investigated the relative benefit of early versus late iron supplementation in low birth weight infants including premature infants. Early treatment was associated with significantly smaller decreases in serum ferritin and hemoglobin levels $(\mathrm{P}<.001)$. In addition, the rate of blood transfusions was lower with early compared with late iron supplementation $(\mathrm{P}=.022)$. There was no difference between early and late supplementation in the number of patients with nectorizing enteroclitis $(\mathrm{P}=.646)$. Sensitivity analysis indicated no one study overly influenced the findings and that the data was reliable.

Our study is consistent with findings that suggest early compared with later iron supplementation may benefit infants with low birth weights. The study of Lundstrom et al. [5] found that in low birth weight infants (1,000 to $2,000 \mathrm{gm})(\mathrm{N}=117)$ that those infants who did not receive iron supplementation ( $2 \mathrm{mg}$ of iron $/ \mathrm{kg} /$ day starting at 2 weeks of age) had a higher tendency (about $80 \%$ of infants by 6 months) to develop iron deficiency compared to those infants who did receive iron supplementation (about $5-10 \%$ by 6 months) [5]. Hall et al. [22] performed a randomized controlled study that compared iron nutritional status in premature infants with birth weight $<1800 \mathrm{~g}(\mathrm{~N}=20)$ who received iron $(1.7 \mathrm{mg} / \mathrm{L}$, $3 \mathrm{mg} / \mathrm{L}$ or $15 \mathrm{mg} / \mathrm{L}$ ) added to premature formula that was fed to the infants during initial hospitalization. They found that the higher iron supplementation $(3 \mathrm{mg} / \mathrm{L}$ and $15 \mathrm{mg} / \mathrm{L}$ ) added at this early timepoint resulted in a reduced frequency of anemia and low transferrin saturation compared with the infants who were given the $1.7 \mathrm{mg} / \mathrm{L}$ iron supplementation [22]. A study by Miller at al. [23] found that there was no difference in conventional measures of iron status in preterm babies (24-32 weeks of gestation) who either did or did not receive iron supplementation (3-12 $\mathrm{mg} / \mathrm{kg} /$ day) when the supplementation occurred relatively late (ie, 7- to 60-days after birth).

Iron deficiency in infancy is associated with growth and neurodevelopmental deficits. Steinmacher et al. [24] in a follow-up study of a prior randomized trial examined whether early compared with late iron supplementation improved neurocognitive and motor development in preterm infants (<1301 gm) [24]. The original study found that early enteral iron supplementation (as early at enteral feeding was possible) compared with late 


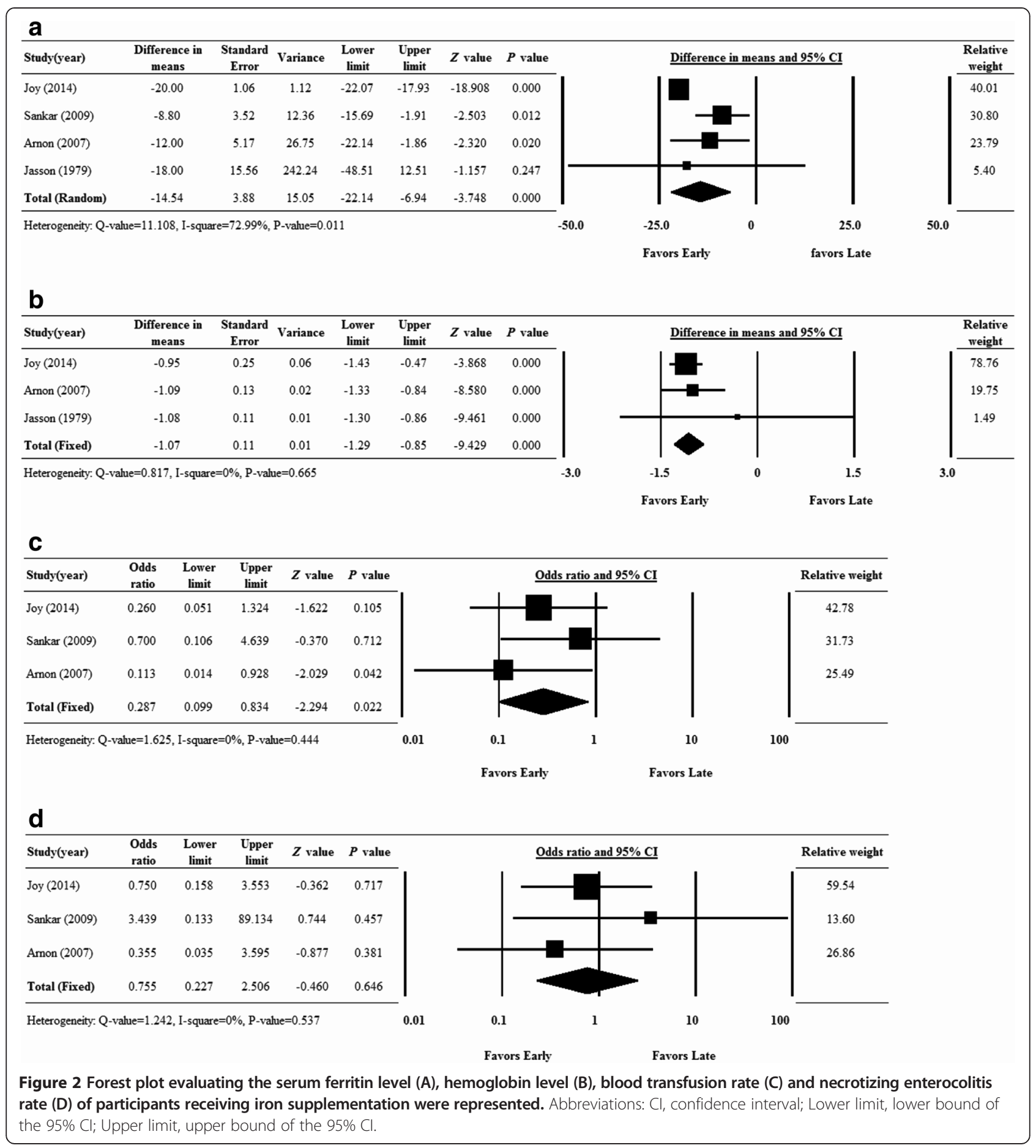

supplementation (Day 61 of life) reduced the frequency of blood transfusions and the incidence of iron deficiency in low birth weight infants [21]. In the follow-up study, they used the Kaufmann Assessment Battery for Children and the Gross Motor Function Classification Scale to evaluate neurocognitive and psychomotor development in children at 5.3 years' corrected age who had been treated with early or late iron supplementation in the original study. The Kaufman Assessment Battery for Children is a standardized test that assesses intelligence and achievement in children aged two years, six months to 12 years, six months. The Gross Motor Function Classification Scale is a scale from 0 to 5 that classifies the severity of motor involvement of children on the basis of their functional abilities and their need for assistive technology. Steinmacher et al. found that early 


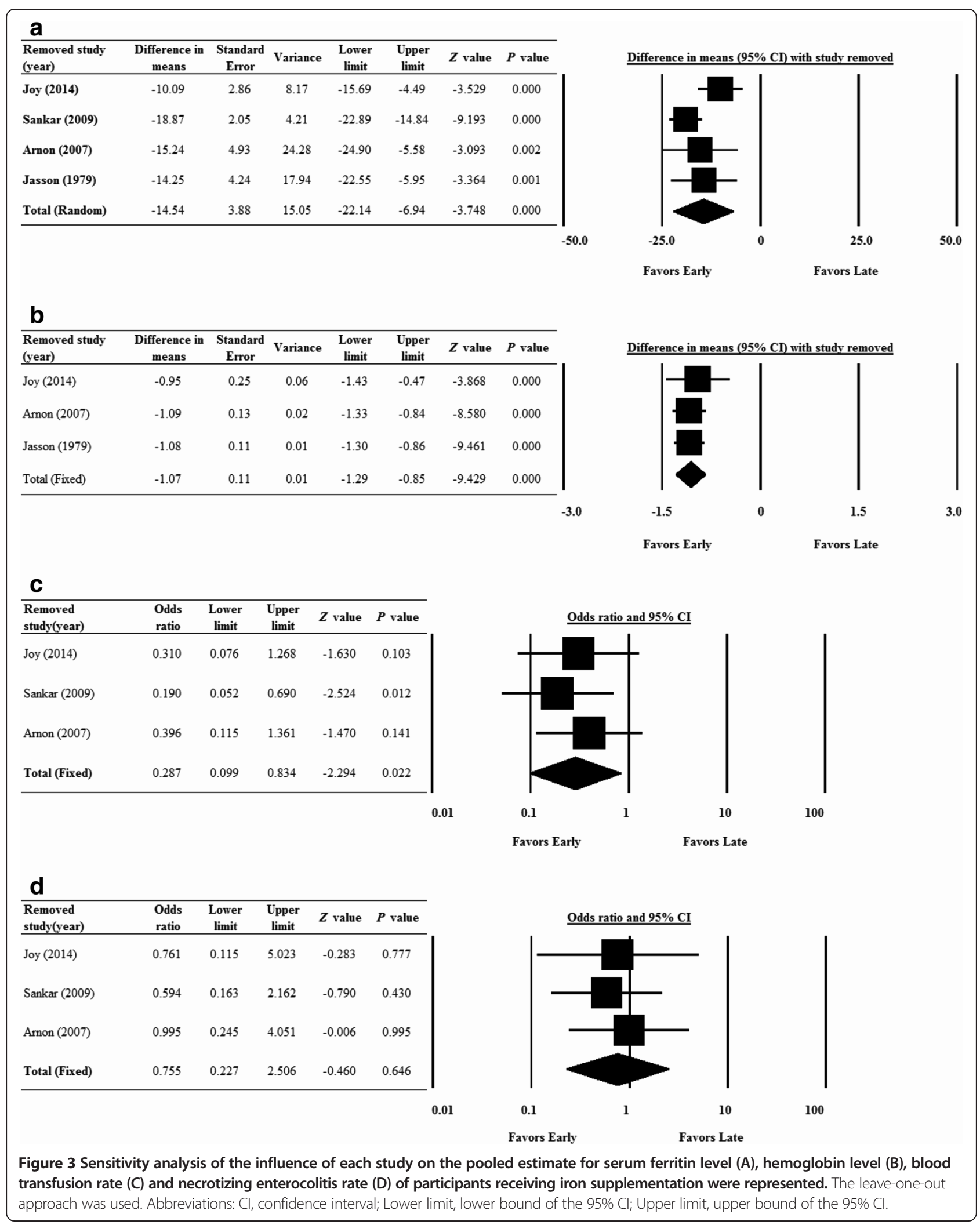


enteral iron supplementation compared with late supplementation was associated with a trend for better longterm neurocognitive and psychomotor development; about $19 \%$ of the early and $35 \%$ of the late supplementation group had abnormal neurological development and approximately $66 \%$ and 54\%, respectively, were without disability. Gross Motor Function Classification Scale score $>1$ was found in $2 \%$ of patients for the early and $7 \%$ of patients in the late iron supplementation group. A limitation of the study was that the original study was not powered to evaluate neurocognitive development.

Two other studies also evaluated the use of iron supplementation in low birth weight infants on cognitive and neurodevelopment outcomes [25,26]. Friel et al. [26] investigated the effect of increased iron intake on hematologic and cognitive status in infants with low birth rate $(\mathrm{N}=58)$. They evaluated two levels of iron supplementation: $13.4 \mathrm{mg}$ iron/L and $20.7 \mathrm{mg}$ iron/L. They found that hemoglobin and Griffith's Developmental Assessment were not different between treatment groups ( $\mathrm{P}$ values $<.05$ ). They did find that the number of respiratory tract infections was higher in the high compared with low iron groups, possibly indicating a detriment for administering high levels of iron. These findings suggest there is no advantage to administering elevated iron to infants with low birth weights.

Ohls et al. [25] assessed the effect of supplementing erythropoietin and iron compared with iron alone on long-term developmental outcomes in extremely low birth weight infants $(\leq 1000$-gm birth weight $)(\mathrm{N}=172)$. Approximately $5 \mathrm{mg} / \mathrm{kg}$ of iron was included in both treatment groups. The study evaluated the need for transfusions, anthropometric measurements, postdischarge events, and developmental outcomes at 18 to 22 months' corrected age. They found no significant difference in weight, length, or head circumferance between the erythropoietin plus iron compared with iron alone groups. There was also no difference between groups in rate or rehospitalization, transfusions after discharge, the percentage of patients with Bayley-II Mental Developmental Index <70 (34\% for erythropoietin plus iron and $36 \%$ for iron alone) or other neurodevelopmental and cognitive functions. The authors conclude that early treatment with erythropoietin plus iron was not of greater developmental benefit than iron alone.

Our meta-analysis only included four studies and the studies were heterogenous with respect to dosage and timing of iron supplementation. For example, the definition of "early" and "late" supplementation varied across studies. Heterogeneity in studies investigating the effect of iron supplementation in low birth infants has been noted before [9] and indicates the need for more consistent designs among studies that investigate this issue. In addition, the iron sources used across the studies differed and had different oral absorption and gastrointestinal tolerance [27], which may have confounded our findings. We also did not evaluate the effect of early versus late iron supplementation on neurodevelopment, cognitive function, or growth. Further studies are required to address these important medical questions. Our findings showed that the early group had a better iron status than late group, which suggest that the prevalence of iron deficiency and iron deficiency anemia may be lower in early supplement group. However, only one included study [21] evaluated iron deficiency, hence, we were not able to analyze this directly. In addition, we did not assess how dose and a more precise evaluation of timing affected the results. This was not possible as the doses across the studies overlapped and the timing was variables. Moreover, only five studies were included in the analysis making it not practical to do subgroup analysis.

In conclusion, early iron supplementation improved serum ferritin and hemoglobin levels in infants with low birth rate. However, caution should be used when treating infants with iron so as not to result in iron overload and possibly negative long-term effects on neurodevelopment [6].

Abbreviations

Cl: Confidence level; OR: Odd ratio; SD: Standard deviation.

\section{Competing interests}

The authors declare that they have no competing interests.

\section{Authors' contributions}

HXJ is the guarantor of integrity of the entire study, RSW helped in editing the manuscript, SJC performed the literature search, APW extracted the data, and $X Y L$ performed the statistical analysis. All authors read and approved the final manuscript.

Received: 18 November 2014 Accepted: 18 February 2015 Published online: 14 March 2015

\section{References}

1. Rao R, Georgieff MK. Iron in fetal and neonatal nutrition. Semin Fetal Neonatal Med. 2007:12:54-63.

2. Makrides M, Anderson A, Gibson RA, Collins $\subset$ T. Improving the neurodevelopmental outcomes of low-birthweight infants. Nestle Nutr Inst workshop Ser. 2013;74:211-21.

3. Ferri C, Procianoy RS, Silveira RC. Prevalence and risk factors for iron-deficiency anemia in very-low-birth-weight preterm infants at 1 year of corrected age. J Trop Pediatr. 2014;60:53-60.

4. Vucic V, Berti C, Vollhardt C, Fekete K, Cetin I, Koletzko B, et al. Effect of iron intervention on growth during gestation, infancy, childhood, and adolescence: a systematic review with meta-analysis. Nutr Rev. 2013;71:386-401.

5. Lundstrom U, Siimes MA, Dallman PR. At what age does iron supplementation become necessary in low-birth-weight infants? J Pediatr. 1977;91:878-83.

6. Rao R, Georgieff MK. Iron therapy for preterm infants. ClinPperinatol. 2009:36:27-42.

7. Gorten MK, Cross ER. Iron Metabolism in Premature Infants. li. Prevention of Iron Deficiency. J Pediatr. 1964;64:509-20.

8. Long H, Yi JM, Hu PL, Li ZB, Qiu WY, Wang F, et al. Benefits of iron supplementation for low birth weight infants: a systematic review. BMC Pediatr. 2012;12:99. 
9. Mills RJ, Davies MW. Enteral iron supplementation in preterm and low birth weight infants. Cochrane Database Syst Rev. 2012;3:CD005095.

10. Anabrees J. Early Enteral Prophylactic iron Supplementation May be Preferred in Preterm Very Low Birth Weight Infants. J Clin Neonatol. 2014;3:14-5

11. Agostoni C, Buonocore G, Carnielli VP, De Curtis M, Darmaun D, Decsi T, et al. Enteral nutrient supply for preterm infants: commentary from the European Society of Paediatric Gastroenterology, Hepatology and Nutrition Committee on Nutrition. J Pediatr Gastroenterol Nutr. 2010;50(1):85-91.

12. Nutrition Committee, Canadian Pediatric Society. Nutrient needs and feeding of premature infants. Nutrition Committee, Canadian Paediatric Society. CMAJ. 1995;152(11):1765-85. http://www.cmaj.ca/content/152/11/ 1765.reprint.

13. Baker RD, Greer FR, Committee on Nutrition American Academy of Pediatrics. Diagnosis and prevention of iron deficiency and iron-deficiency anemia in infants and young children ( $0-3$ years of age). Pediatrics. 2010;126(5):1040-50

14. Higgins JP, Thompson SG. Quantifying heterogeneity in a meta-analysis. Stat Med. 2002:21:1539-58.

15. Hozo SP, Djulbegovic B, Hozo I. Estimating the mean and variance from the median, range, and the size of a sample. BMC Med Res Methodol. 2005:5:13.

16. Sutton AJ, Duval SJ, Tweedie RL, Abrams KR, Jones DR. Empirical assessment of effect of publication bias on meta-analyses. BMJ. 2000;320:1574-7.

17. Joy R, Krishnamurthy S, Bethou A, Rajappa M, Ananthanarayanan PH, Bhat BV. Early versus late enteral prophylactic iron supplementation in preterm very low birth weight infants: a randomised controlled trial. Arch Dis Child Fetal Neonatal Ed. 2014;99:F105-109.

18. Sankar MJ, Saxena R, Mani K, Agarwal R, Deorari AK, Paul VK. Early iron supplementation in very low birth weight infants-a randomized controlled trial. Acta Paediatr. 2009;98:953-8.

19. Arnon S, Shiff Y, Litmanovitz I, Regev RH, Bauer S, Shainkin-Kestenbaum R, et al. The efficacy and safety of early supplementation of iron polymaltose complex in preterm infants. Am J Perinatol. 2007:24:95-100

20. Jansson L, Holmberg L, Ekman R. Medicinal iron to low birth weight infants. Acta Paediatr Scand. 1979:68:705-8.

21. Franz AR, Mihatsch WA, Sander S, Kron M, Pohlandt F. Prospective randomized trial of early versus late enteral iron supplementation in infants with a birth weight of less than 1301 grams. Pediatrics. 2000;106:700-6.

22. Hall RT, Wheeler RE, Benson J, Harris G, Rippetoe L. Feeding iron-fortified premature formula during initial hospitalization to infants less than 1800 grams birth weight. Pediatrics. 1993;92(3):409-414.24.

23. Miller SM, McPherson RJ, Juul SE. Iron sulfate supplementation decreases zinc protoporphyrin to heme ratio in premature infants. J Pediatr. 2006:148(1):44-8

24. Steinmacher J, Pohlandt F, Bode H, Sander S, Kron M, Franz AR. Randomized trial of early versus late enteral iron supplementation in infants with a birth weight of less than 1301 grams: neurocognitive development at 5.3 years' corrected age. Pediatrics. 2007:120:538-46.

25. Ohls RK, Ehrenkranz RA, Das A, Dusick AM, Yolton K, Romano E, et al Neurodevelopmental outcome and growth at 18 to 22 months' corrected age in extremely low birth weight infants treated with early erythropoietin and iron. Pediatrics. 2004;114:1287-91

26. Friel JK, Andrews WL, Aziz K, Kwa PG, Lepage G, L'Abbe MR. A randomized trial of two levels of iron supplementation and developmental outcome in low birth weight infants. J Pediatr. 2001;139:254-60.

27. Patil SS, Khanwelkar CC, Patil SK. Conventional and newer oral iron preparations. Int J Med Pharm Sci. 2012:2:16-22.

\section{Submit your next manuscript to BioMed Central and take full advantage of:}

- Convenient online submission

- Thorough peer review

- No space constraints or color figure charges

- Immediate publication on acceptance

- Inclusion in PubMed, CAS, Scopus and Google Scholar

- Research which is freely available for redistribution

Submit your manuscript at www.biomedcentral.com/submit 